III. Construction of a new imaginary of the city and public space: Saraus movement, mobility and religion

\title{
City as mobility: \\ a contribution of brazilian saraus to urban theory
}

\author{
Derek Pardue \\ Department of Global Studies, Aarhus University, Denmark
}

Lucas Amaral de Oliveira

Programa de Pós-Graduação em Sociologia, Universidade de São Paulo, Brasil

\begin{abstract}
The article analyzes saraus movement - poetry readings in São Paulo's periphery - as a cultural phenomenon that over recent years has transformed the city space into a vibrant socio-political project. The movement offers important insights for an anthropology of cities by highlighting the materiality of mobility and spatiality, understood here as a set of social and cultural practices that involve the existential knowledge, social networking, and local community empowerment gained from mobility between predominantly peripheral neighborhoods and urban labor centers. We examine how saraus contribute to the construction of a new imaginary of the city and public space occupied by the socially excluded and racialized peripheries. We provide an analytical and empirical contribution to city production and urban theory, and demonstrate that mobility and the encounter are not simply temporary extraneous interactions, but rather experiences constitutive of social knowledge.
\end{abstract}

Keywords: Urban Theory, City, Saraus, Mobility, Community Empowerment. 


\section{A cidade como mobilidade:}

\section{uma contribuição do saraus para a teoria urbana}

\section{Resumo}

O texto analisa o movimento dos saraus das periferias paulistanas como fenômeno cultural que, em anos recentes, vem transformando o espaço urbano em um vibrante projeto sócio-político. O movimento oferece insights importantes para pensar uma antropologia das cidades na medida em que possibilita evidenciar a materialidade da mobilidade e da espacialidade, entendida, aqui, enquanto conjunto de práticas sociais e culturais que envolve conhecimento existencial, formação de redes e empoderamento comunitário adquiridos mediante a mobilidade urbana. De modo geral, buscamos examinar de que forma os saraus podem contribuir para a construção de um novo imaginário da cidade e do espaço público ocupado pelas periferias socialmente excluídas e racializadas. $\mathrm{O}$ argumento central do artigo sugere uma contribuição analítica e empírica para a teoria social urbana e para os processos de produção da cidade, demonstrando que a mobilidade e o encontro não são apenas interações temporâneas e alheias, mas sim experiências constitutivas do próprio conhecimento social.

Palavras-Chave: Teoria Urbana, Cidade, Saraus, Mobilidade, Empoderamento Comunitário. 


\title{
City as mobility: \\ a contribution of brazilian saraus to urban theory
}

\author{
Derek Pardue; Lucas Amaral de Oliveira
}

In the turbulent late 196os, Henri Lefebvre declared that the city is a "virtual object," the work of historical and social agents, who produce it through an uninterrupted succession of conduits, decisions, and messages (Lefebvre, 1968). In the same vein, David Harvey added that Lefebvre's famous slogan of people's "right to the city" would depend on the ability of social and cultural movements to give meaning and intelligibility to the city and to institute new modes of urbanization (Harvey, 2012). More recently, anthropologist Michel Agier, in an attempt to escape the trappings of an urban social theory with no empirical object, argued that it is necessary to consider the processes of "city-making" as essential in our assessment of the "right to the city" (Agier, 2015). In the following discussion of saraus ${ }^{1}$ - open mic events - we demonstrate that poetics of the performers reveals an insight into the materiality of mobility. In other words, saraus not only represent an emergent circuit of cultural production in the working-class urban periphery, they also highlight the trajectories of participants and everyday life as part of "city-making," frequently articulated through banal but meaningful landmarks.

Sarau performers use the everydayness of urban mobility as a rhetorical resource. Movement is momentarily captured in things like alleyways, bridges and public sewers that function as city rivers. In this manner, sarau participants demonstrate what sociolinguist Alastair Pennycook described as "ways in which language practices and language localities construct each other" (Pennycook, 2010: 10). This poetic transformation and performative deployment is important because it demonstrates the geographic force of mobility. Our argument is that saraus contribute to a city-making in this respect and thus support the idea of Lefebvre, Agier and other scholars that the city is not an a priori given entity but rather a dynamic result of sociocultural production. Given the social fabric and discursive materiality of saraus, they also contribute to the argument that the sociocultural production of the urban is a political negotiation involving power relations (Harvey, 2005).

\section{A Brief Contextualization}

"The sarau is for who doesn't exist, not for who does."2 With these words, Sérgio Vaz, the founder of Cooperifa ${ }^{3}$ and one of the leading voices of the saraus community, established a motto and ideological base for the contemporary open microphone grassroots movement led by disenfranchised populations in urban Brazil. Vaz used this phrase several times in a workshop in 2010 with the implication that it had already become a stock phrase: a simple opening salvo for those unaware that the sarau is a critical performance targeting issues of social status and rights to the city.

\footnotetext{
1 Unsurprisingly, the term itself contains multiple etymologies, all leading to Europe (Latin, Catalan, Galego) and all indexing tardiness. The sarau is a performance of late growth, a loose tongue, a brainstorm of potential plans for tomorrow. We discuss this term in more detail later in the section "Saraus as Cultural Critique."

2 The phrase works better in Portuguese: "O sarau é para quem não é, não para quem é."

3 This name refers to the Cooperativa Cultural da Periferia, a neologism combining "cooperative" with "periphery."
} 
The sarau as a poetic, and at times political, speech genre has a long history in Brazil, which reveals important markers of nation building and socioeconomic class by distinctively connecting speakers and texts to Western Europe and bourgeoisie notions of culture and art (Medeiros, 2002). It has frequently represented tension, a dissonant note of critique, which in its current iteration has become a fundamental component of its existence. However, the contemporary sarau running through the urban peripheries has garnered greater attention from state culture and education agencies. As Bin (2009), Nascimento (2006; 2009), Silva (2011) and Tennina (2013) demonstrate, the saraus have been essential in the expansion of so-called "marginal literature" in that they give visibility to the literature produced in and by the workingclass urban periphery, fostering its publication, practice and consumption.

However, while academic and activist communities have been quick to discuss the ideological significance of the contemporary sarau in terms of empowerment and literary importance, little has been said about the movement's spatial contours. ${ }^{4}$ Saraus offer an insightful case study for a more general theory of cities that highlights spatiality, understood as a set of social practices that involve the existential knowledge and social networking acquired from mobility, rather than a conventional notion of networks based on static indices of geographic and cultural presence.

We are certainly not advocating a diminishment or even a dismissal of the power of the sarau as part of agency on the periphery. The work of dozens of activists, ${ }^{5}$ as well as that of scholars like Nascimento (2010; 2014), Tennina (2010), Silva and Tennina (2011), Pardue (2014), Muniz Jr. \& Oliveira (2015), Silva (2011), Hapke (2012) and Smith (2015), provide cross-cultural demonstrations that poetry contributes to an individual and collective desire for change. Recently, Leonora Souza Paula (2016) analyzed the ways in which the movement of marginal literature and saraus renders a social vision of the world in which the periphery is no longer understood and represented as a stigmatized culturally impoverished space, but rather as a legitimate site of enunciation representing locally lived experiences. In this sense, saraus seem to stoke the drive to survive this world and imagine another, what the inspirational US black feminist lesbian writer Audre Lorde (1985: 36) once expressed as "what we [black women] feel within and dare make real."

Our article "places" this empowering rhetoric and, in effect, extends what local actors and social movements are already saying, thereby bringing these logics into dialogue with urban theorists and cultural geographers of São Paulo. Our inductive approach to saraus suggests an alternative to urbanization in terms of perpetuating a center-periphery spatial dynamic and the growth of high-surveillance gated communities. By contrast, saraus reveal a set of working-class, subaltern, migrant identifications that has emerged not simply through local community empowerment, but also through circuits, interactions and mobility.

\section{Position in the Field}

This text builds on a selection of interdisciplinary scholarship related to cities, space and expressive culture, and addresses a conceptual gap identified in this field. Urban mobility researchers, for instance, are predominantly concerned with empowerment in terms of institutional access via labor, education and conventional cultural centers (see Gupta and Yesudian, 2006; Nyanzi et al, 2005; Zentgraf, 2002). By contrast

\footnotetext{
4 One exception is José Carlos G. da Silva (2011). While the analysis in his article focuses primarily on rap lyrics and hip hop posse organization, Silva points to a vital connection between hip hop, saraus and marginal literature movements as practices that demarcate "spatial-symbolic frontiers" in the city (see Silva, 2011: 91).

5 For example, the volume Polifonias Marginais, an important work edited by Ingrid Hapke, Mario Augusto Medeiros da Silva, Lucía Tennina e Érica Peçanha do Nascimento (2015), brings together interviews with writers and activists from the marginal and black literary movements as well as the saraus community. Collaborators include Allan da Rosa, Alessandro Buzo, Binho, Dugueto Shabazz, Elizandra Souzam Esmeralda Ribeiro, Ferréz, Raquel Almeida, Sacolinha, Sergio Vaz, Sonia Regina Bischain, and Zinho Trindade.
} 
to such frameworks, spatial networks involve housing and transportation, and indeed sarau performers reflect on residential spaces and commuting experiences. They criticize the shortcomings of conventional educational institutions and cultural centers as both ideologically and geographically exclusionary. Through provocative manifestos and emotive neologisms, marginal poets deconstruct such conventional categories of urban mobility. The distinction to which we draw attention here is the material significance of these rhetorical expressions and the role of materiality in the sociopolitical movement of so-called marginal literature.

The overt performativity of saraus creates alternative geographies through the use and representation of alternative trajectories of urban mobility. We draw from the work of cultural geographers and anthropologists like Werlen (2004) and Haesbaert (1997) who help us distinguish "environment" from "landscape" by emphasizing the role of social interpretation in the latter. We contribute to this literature by connecting expressive performance - such as music-making and poetry reading - with place. In so doing, we also enter into dialogue with scholars from the field of sound studies, like Cohen (2012) and Roberts (2012), who underscore the role of assemblage in sonic perception and its parallels with spatial orientation. We borrow from architect Bernard Tschumi's conception of architecture as the activation of space by the movement of bodies (see Cleary, 2017) in order to show that the articulations of everyday mobility by sarau performers produce a new infrastructure of the periphery, attributing new names, meanings, shapes and significance to the previously disregarded and overlooked. Finally, underpinning our own work and that of the colleagues cited above is an appreciation of the mutual intersections between objects and people (Urry, 2007).

Mobility and networks in this article are simultaneously straightforward conventional terms for physical movement and sociality, but also theoretical provocations to get us to think about urban space as a dynamic matrix of encounters. Following Doreen Massey, the meaning of spaces and places is discursively and temporally structured. It is the accumulation of narrative weight that makes the street corner or condominium salient as a point of protest or community: "if space is rather a simultaneity of stories-sofar, then places are collections of those stories, articulations, within the wider power-geometries of space" (Massey, 2005: 130). Peripheral places in São Paulo appear to be mere surfaces, rudimentary scratches in the pragmatics of life and/as labor. "There is no culture" there, citing the long-standing popular view of Brazilians regarding the sprawling favelas. The point is not just that there is indeed culture in the periphery but that the "there" is not static; rather, it is a product of mobility and encounters.

Theories and observations regarding "flexible citizenship" (Ong, 1999) and "shared economies" (Kostakis and Bauwens, 2014) imply processes of accumulating power through movement. Indeed, trajectories can be empowering. Similarly, displaced migrants often have little control over their movement and thus trajectories become devoid of power. Refugee mobility, for example, affords little in the way of knowledge or power. The logic of such paradigms is limiting, and excludes many of the peripheral realities and specifically the social action of cultural and urban movements. Instead, the saraus demonstrate, in an outwardly performative fashion, that marginal, out-of-the-way places and people construct their own circuits, not as hermetically sealed enclaves of subalternity, but as competing trajectories vying for control over city spaces. Furthermore, in so doing they periodically (and often strategically) enter into dialogue with conventional cultural, educational and even financial institutions. In this manner, saraus exemplify what Agier describes as a cidade bis - that is, a possibility to:

[...] design a multiple city, starting from the perspective of practices, relationships and words that inhabitants, such as those of the ethnographic researcher, observe, collect, note, directly and situationally, and that this city is not less real than that of the architect or urban planner or city administrator. It is different. (Agier, 2015: 486) 
The sarau is one example of the collective design that Agier describes. But before analyzing the performative material, we need to address the issues of access, elicitation and methodology.

\section{(Performative) Methodology}

The data presented in this article is taken from fieldwork research conducted between 2010 and 2015. We used contacts from former research with hip hop performers and writers from the periphery, as well as a knowledge of living in São Paulo accumulated in different moments of our lives. The sarau fieldwork consisted of attending and participating in a variety of events, many of which normally occurred on a weekly basis. These include literary meetings, saraus, slams ${ }^{6}$ (poetry battles), writer workshops, conferences, and international book fairs, as well as local literary activities and public debates on periphery culture and public policies. The web of saraus is extensive. For the purposes of this article, we have given particular attention to the following: Sarau do Binho, Suburbano Convicto, Cooperifa, Slam da Guilhermina, Sarau Poesia da Brasa, and Mesquiteiros. ${ }^{7}$

We consulted monthly publications such as the Agenda Cultural da Periferia, organized by the NGO Ação Educativa, and the Mapa Cultural da Quebrada, a project run by the Solano Trindade Popular Agency in Embu municipality (today part of an extended South West periphery of São Paulo). ${ }^{8}$ In addition, we consulted Boletim do Kaos, edited by writer Alessandro Buzo, the founder of Suburbano Convicto Productions. We also participated in social networks and listservs dedicated to the development of cultural collectives and marginal literary events throughout the city.

Part of the impetus for this article arose from a methodological question. Whereas the various publications mentioned above imply a particular sarau geography in terms of event location, they do not tell us anything about the urban trajectories of participants. We decided that a questionnaire might be the best solution. However, a question remained: how should such a questionnaire be distributed during what can only be described as an intense performance? The answer was to create a performative methodology. Below we describe a strategy used by one of the authors, Derek Pardue, and, for this reason, the personal pronoun "I" appears. We decided to employ this discursive shift and include this brief vignette because the methodology directly relates to sarau performativity, while also exemplifying the kind of bis city described by Michel Agier.

Despite the fact that Brazilians, especially young people, have closed the information and communication technology gaps in recent years, in part due to the unprecedented public and private stimulation of consumption via social media platforms (see Nishijima et al., 2016; Sorj and Fausto, 2015; Holmes, 2016), some acts of communication, like a foreign anthropologist asking for access permission, need to be done in person. It was clear that I needed a flexible and dynamic methodology based on interpersonal skills, especially with the sarau organizers, and a concise, entertaining pitch to convey my

\footnotetext{
6 Slam is a worldwide known competition in which poets recite original poetry. The performances are judged and given numerical scores by pre-selected members of the audience. This format arrived in Brazil in 2008, and was popularized predominantly by the Núcleo Bartolomeu de Depoimentos with their ZAP-Slam events.

7 Within this group, it is important to mention two sites as particularly significant for our reflection: Suburbano Convicto Bookstore (SCB), created and managed by writer Alessandro Buzo, and the Sarau do Binho, created by poet Robinson Padial and his wife Suzi Soares. The SCB is the only bookstore dedicated exclusively to marginal literature. These two sites hold a special status, because the former displays a mix of veteran and newcomer authors while the latter functions as an obligatory rite of passage for writers. The Sarau do Binho is where one enters the market of "marginal”. Moreover, Binho along with Suzi Soares are responsible for the organization of a large portion of all literary events in the whole south side area of São Paulo.

8 Solano's great grandson, Zinho Trindade, is a leading presence in the sarau and marginal literature movement.
} 
idea to the event's participants. Again, my experience with hip hoppers, ${ }^{9}$ as well as being a public lecturer and a scholar, helped me engage with difference and ultimately produce a significant response about what upon first glance seems esoteric - urban mobility, transportation trajectories and a sense of community.

Following the spirit of the sarau, I shouted my story. A clueless gringo wanderer, who in the late $1990 \mathrm{~s}$ got lost in the urban peripheries and discovered a great many life truths and learned something of the art of marginality. "The periphery became a place I go when I get confused about the world." I made a selfdeprecating joke and quickly arrived at the point - the importance of place and movement in everyday life. I then asked permission to distribute a short questionnaire with the goal of mapping the neighborhoods and the traveling involved in these saraus. What was implicit in my speech and what is more explicit when performers insist that saraus are periphery "window displays" (to be discussed below) is that the rush of arrivals and anxious expectations of performances are event highlights.

Four performative introductions by Pardue at four different saraus during June and July of 2014 produced 214 entries. To summarize, the quantitative data clearly shows us that the overwhelming majority $(84 \%)$ of participants used public transportation (some combination of buses, mostly, followed by the subway and less frequently trains) to arrive at the events. The responses to the question "where do you live" shows a remarkable geographical distribution with over $50 \%$ of replies indicating a neighborhood outside of the district, thereby bolstering the argument that saraus are not simply local events: in fact, they attract significant numbers from farther afield and prove to be a consistent element in sarau sociality. Crosstown trips comprise discursive resources for marginal poets to articulate individual and collective experiences and knowledge.

\section{Saraus as Cultural Critique}

The contemporary form of the sarau involves a strong identification and presence in the urban peripheries of Brazil, especially in the country's biggest city, São Paulo. Such a move to the scattered public spaces of the periphery led by the working poor of Brazilian society might appear odd were one to read the short stories of Machado Assis, ${ }^{10}$ the magnificent author of Brazilian realism and master of subtle sarcasm, who promoted saraus as a young writer during the 1860 .

In contrast to the sarau events of today, the saraus of Assis's time were "recitals," i.e. distinct cultural events in bourgeois salons of the nineteenth century, held predominantly in Rio de Janeiro and later in São Paulo. These were occasions to "elevate" poetry to a "fine art" of elite "good taste," which, in this case, meant an approximation with the customs of European haute culture. According to critic Roberto Schwarz, this kind of social and artistic gathering, commonplace in many Parisian salons of the aristocracy, was important for Brazil to mediate its relationship with Europe. Within the arts, the sarau became a forum to simultaneously transport and mimic traditions, as well as "adopt, quote, ape, rob or devour the mannerisms and styles in a way that they could reflect the kind of cultural knot in which we find ourselves" (Schwarz, 2009: 76-77). The sarau was thus an arena to work out personal and collective anxieties around "being civilized" and "having culture."

\footnotetext{
9 See, for instance, Pardue (2008), especially the introductory chapter, and Pardue (2009) as particular examples of performative methodology regarding hip hop research in São Paulo.

10 Saraus and salon gatherings periodically appear in Assis's novels and short stories (Assis, 2007). One example of the latter is "Um Homem Célebre" ("A Famous Man"), originally published in Gazeta de Notícias in 1888.
} 
In Brazil, the sarau dates back to the early nineteenth century with the arrival of the Portuguese royal court in the colonial capital of Rio de Janeiro in 1808 . It would not be until a century later, though, that the genre would find a home in São Paulo via the elite class of coffee barons, who acted as patrons to avantgarde art and philosophical movements. As shown in the research of Ana Luiza Basilio and Jéssica Moreira (2014), Silva (2004), Camargos (1999) and Saliba (2001), salons such as Villa Kyrial in the Vila Mariana neighborhood featured saraus as part of their aesthetic agendas and contributed significantly to the cultural infrastructure during the early decades of the twentieth century - the belle époque of São Paulo elite life. Silva argues, in fact, that Villa Kyrial, for example, was "most probably the birthplace of the idea to hold the Modernist Week of 1922, one of the most important events for São Paulo artists" (Silva, 2004: 24). In complementary fashion, Camargos (1999) describes the political role of saraus in salon spaces during Brazil's transition from an oligarchy in the First Republic (1889-1930) to a populist government, albeit in the form of dictatorship, under Getúlio Vargas (1930-1945).

The resurgence of saraus in contemporary urban peripheral culture is both a continuation and a significant break with the past. These festive rants, generally nocturnal affairs with a literary focus, resurfaced in a robust manner in hole-in-the-wall corner bars of the urban peripheries on the South Side of São Paulo. The geographical trajectories have moved farther south, away from Vila Mariana, and the discourses are not of an anxious but hopeful wait for cultural modernization (or "Europeanization") but rather of an anxiety concerning the present failures of modernity. "In the periphery, the desire to speak was so great that the people wanted to do something. They wanted to produce stuff. So, there were many folks who hung out at the bar and who ended up becoming poets," relates Binho, one sarau founder. Sérgio Vaz, following a similar logic, often says that the contemporary sarau in the urban periphery occurs "when poetry comes down from the pedestal and kisses the feet of the community." ${ }^{\prime 1}$

In the period from the late 1990 s to the early 2000s, this cadre of writers and cultural producers achieved an artistic transformation of their respective neighborhoods. The pioneer projects on the South Side include: Cooperifa in Jardim São Luís, founded in 2001 by poets Sérgio Vaz and Marco Antonio Iadocicco (aka Marco Pezão); Sarau do Binho, in Campo Limpo, founded by Robinson Padial (aka Binho) and Suzi Soares. Binho's sarau has operated since 2004 as a poetic sarau, but it existed earlier in a slightly different version under the name of Noite da Vela. These saraus continue to operate regularly today and are still organized by poets and activists of the marginal literature movement.

Nascimento (2009; 2011), a leading scholar of saraus and marginal literature, recognizes in the movement an elaborate arrangement by artists to stimulate new leisure options for creativity and participation. In so doing, the sarau reveals new forms of association among community members that promote a diversity of social action, empowerment and ways of being in (estar) and being of (ser) the periphery. Sarau participants tend to frequent multiple saraus and develop a sociogeographical circuit of expressive culture. In this light, the circulation of authors is highly significant, because it empowers actors to create and maintain translocal networks, thereby increasing the visibility of the movement as part of the urban fabric. The result is that their "own" sacred spaces become stronger and cultural dissemination of their texts easier.

Keeping in mind both Nascimento's work and the sarau founders' periphery-centric manifestos, we can move to the next section of the article. Having provided a basic account of sarau history and its social function, we shift the reader's attention to the main contribution of saraus to urban theory. Our argument rests on two interconnected points. First, it is essential to recognize the periphery as a network of cultural creativity and not simply an object of artistic representation. Second, as a vehicle of marginal literature,

11 This quote from Binho was published by the journalist Leandro Cruz (see https://goo.gl/GOClpT). The phrase from Vaz is standard jargon used by the poet, not unlike the opening phrase of this article. 
saraus create geographic value through a mixture of recuperated landmarks, resignified banalities of public space, and knowledge-building from urban travel. The second point follows on from the first and provides an insight into a particular cultural geography of the city.

\section{The Urban Periphery as a "Center" of Cultural Production}

Brazilian and Brazilianist scholarship spent the first decade of the twenty-first century documenting the cultural value of the periphery. ${ }^{12}$ What connects this interdisciplinary scholarship is an urgent need to show that when confronted with increasing inequality and high rates of violence during the 199os, significant numbers of residents used artistic practices to give value to their communities. Furthermore, performers organized themselves into collectives so that the shared experiences and articulations of marginality and the urban periphery have become a link between artistic production and social reality (see Nascimento, 2011; Oliveira, 2016).

In the following passage taken from a documentary film on saraus, Vaz describes their advent as a grassroots literary movement that transformed state abjection into cultural production:

In the periphery, there is no theater, no museum, no library and no cinema. The only public space that the State allowed was the bar. They thought we would just end up drinking cachaça [a popular sugar cane liquor], but we transformed the bar into a cultural center [...]. Their plan went down in flames, because the State lost control of us: what the periphery certainly does not lack is bars. (See Curta Saraus, 2010) ${ }^{13}$

Vaz's declaration underscores that saraus are a result of cultural activism, a grassroots operation that privileges pedagogical politics and stimulates readership and textual creativity in a way that develops literary circulation, the symbolic (and real) consumption of local goods, as well as the promotion of new authors. In his book Rebel Cities, David Harvey discusses the tight but not totalizing link between urban planning and State/elite control. While saraus do not demonstrate anti-capitalist rebellion or revolution at the level of spectacle that Harvey describes (see, for example, Harvey, 2012: 115-119), they do show the development of alternative economies and socialities at the everyday level of regular assemblies and periphery-based routes of mobility. If art is a medium through which people not only imagine but also construct and commodify social realities, then what sort of landscapes and other material effects are produced?

Similar to what happened with hip hop, marginal literature redefines urban spaces. Moreover, the process of creating new cultural landscapes and social networks often affirms a tension and a contradiction present in urban life. Marco Pezão's poetry demonstrates this idea:

Who are you, worker / Who waits before sunrise for the same old bus / To take you like a packed can of sardines | To one more day of work / Making more wealth for the boss // Who are you, brother / smelling like cachaça | with the breath of a no-nutrient meal / You get a ride back home in a VW bus / Given up / Defeated / Just looking for a little peace and quiet / A hot meal / After giving all your blood and sweat, of which there isn't much / To someone who just gets fat // Shit is fat, bro / It's just like that / What chance do we have / On this ride of life? |

12 With regard to the marginal literature movement, we can cite the work of Nascimento (2009), Silva (2013), Silva (2011), Patrocínio (2013), Oliveira (2016), Salom (2014), Eslava (2004; 2008), Reyes (2013) and Tennina (2010); music in D’Andrea (2013), Felix (2005), Pardue (2008) and Salles (2004); audiovisual expressions in Cota (2008), Costa (2009) and Aderaldo (2013; 2016); and other performative art in Levinson (2005) and Pereira (2010).

13 Transcribed from a clip of Sérgio Vaz in Curta Saraus (2010). The film provides a panoramic view of saraus that take place in various bars throughout the São Paulo periphery, especially in the South Side regions of Capão Redondo, Jardim São Luís and Campo Limpo. See: www.curtasaraus.blogspot.com.br/. Accessed on $20 / 10 / 14$. 
If you're from the periphery / You're hanging on the edge like a moustache / Close to the mouth, but always on the outside looking in. (Pezão, 2013: 55)

The worker's life conditions - living far from the workplace and downtown, the long bus ride, always crowded - all of this routine, interspersed with alcohol, desire, unhealthy food, exhaustion, is viscerally present in Pezão's text. We can utilize part of Agier's theory of “city-making” to understand Pezão's iteration and its wider representation of sarau social geography. For Pezão and Agier alike, the concept of "margin" is best understood as:

[...] an epistemological and political position: to understand the limit of what exists - and what exists under the official appearance and what is recognized as done, established, ordered, central and dominant - allows one to perceive the dialectic of the empty and full and describe what, emergent from almost nothing or from an apparently chaotic State, makes the city. (Agier, 2015: 487)

The contingencies central to the everyday lives of periphery dwellers commuting from suburb to center, as Pezão describes in brief but affective minutia, help define São Paulo. The drain of the haul to work, a trajectory of emptiness, is challenged and potentially inverted or "refilled" through the alternative trajectories of saraus and the re-ordering of the mundane.

The city exists not only as a backdrop, but also as a constitutive element in the literary construction. Using the material of everyday violence, marginal poets reorganize the cityscape through their social experiences, and in so doing construct alternative perspectives of the city:

Rough inclines, corners in raw flesh / drumming heartbeat where the weak don't dare to tread / Puddles accumulate serene, orange acids / and apocalyptic trumpets playing fun( $(\mathrm{k}) \mathrm{anon}^{15} /$ announce faithful litters birthed from the Evangelical songs / TV and Nigerian beauties made out of steel / SP, a (precious) stone jungle / And, don't be fooled, son / here, everything is just this way: this zone, this tumult. / On New Year's Eve there's a road race / one called São Silvestre / and it's just like this, fast and furious, that we run all year long. / A funky, diabolic lyre in São Paulo heats everything up. / Upside down SP, Piratininga, punga, uma pinga / and the lyrics escape the elitist salon, naked running in the streets. | Baticum. It's a communal cry. A prayer, some slang [...]. (Danziger, 2012: 64-65)

Inherited from rap, the poetry's orality is fundamental here as the author articulates his belonging in a literary form and places the city as the pivotal point for discussion. This kind of imaginary is distinctly urban and runs counter to the trends toward "deterritorialization" within narrative theory (Tavares, 2001). Furthermore, poets valorize individual testimony as it relates everyday situations focused on social issues and moments of inspiration in a fragmented city. The famous poem "Nóis é Ponte" ("We 'is' the bridge") ${ }^{17}$ by Pezão, often recited in saraus throughout São Paulo, makes explicit the link between existential angst and urban materiality:

\footnotetext{
14 Poem by Marco Pezão, "Pendurados." Original text: “Quem é você, operário / Que antes do clarão do sol espera o buso / Pra te levar enlatado, mordido / Pra mais um dia de trampo / Proporcionar a riqueza do patrão // Quem é você, irmão / Que cheirando à cachaça / Bafo de rango mal nutrido / Volta nessa lotação | Se entregando / Se encoxando / Querendo um aconchego / Um prato quente / Depois de dar o sangue, que já é pouco / A quem só faz engordar || Barra, meu chapa / É foda, chegado / Que chances temos / Na aventura da vida? / Quem é da periferia / Tá ao redor feito bigode / Perto da boca, mas sempre por fora."

15 Bombastic bass-heavy pop music.

16 Excerpt from Walner Danziger's poem “Eles não usam Black Power.” Original text: “Ladeiras ásperas, esquinas em carne viva / coração-tambor onde os caras pálidas não ousam pisar / Poças acumulando ácidos serenos alaranjados / e trombetas apocalípticas do fun(k)anhão / anunciam ninhadas fiéis emergindo em cânticos evangélicos / belezas televisivas e nigerianos de aço. / SP, (S)elva de (P)edras (preciosas) / E não se engane não, moço, / que por aqui é tudo assim mesmo: essa zona, esse alvoroço. / Na virada tem corrida pedestre / uma tal de São Silvestre com largada no ano novo / e é desse jeitinho, velozes e furiosos, que a gente corre o ano todo. / Uma lira paulistana endiabrada esquentando a chapa. / Paulicéia Desvairada, Piratininga, punga, uma pinga / e a letra fugindo do salão elitista, nua correndo pra rua. / Baticum. É reza, gíria [...]”

17 Nóis is a popular, grammatically "incorrect" way of saying we, followed by the third person singular conjugation of the verb "to be" (is or é in Portuguese) rather than the first person plural (are or somos).
} 
Conjugate this verb / Errant consonance / As a manner of speaking // We is the bridge (Nóis é Ponte) and we crosses any river. // The "we" for us / It is singular / The "we" for us / The plural is personal // We is the bridge and we crosses any river. // [...] Show your strength / Face reality / Leave aside the bad / Without being all good / If not, the world will make you crazy / And no one is a biscuit / to let yourself be eaten. // We is the bridge and we crosses any river. // Find another shore / Being smart is not a crime / Rainbow, lagoon / It's all good / Hold the rudder firm and cross the bridge. // Come periphery // We is the bridge and we crosses any river. (Pezão, 2013: $124-125)^{18}$

Pezão's text demonstrates an intertextuality with the rap song "Da ponte pra cá" ("From the bridge to here") by the legendary rap group Racionais MC's. In both cases, social agency mediates urban scenes of tension and thus serves as a political instrument. The protagonist's trajectory functions as a base from which one can interpret the collective experience. The bridge is simultaneously a metaphor of encounter and of separation. The dialectic of interaction and isolation is even more pronounced in the following poem, published as part of the edited volume Coletivo Cultural Poesia na Brasa:

The elite meet in the huge shopping centers, surrounded by the periphery that they themselves invented / the periphery arms itself and terrifies the central elite / In armed warfare, the rich oppress the impoverished with state force via the police / But, now things are different, the periphery arms itself in another way / Now, the weapon is knowledge, the munition is the book and the shots come from the text [...]. (Brasa, 2009: 31-32)19

One can identify here an attempt to construct a reading of the city that not only alters the way residents of the periphery are labeled, but also the manner in which residents conceive of collective identities and how they construe social space in general. Akin to Massey's conceptualization of "place" (see Massey, 2005: 5-6), sarau performers often mobilize the local, not in retreat into a barricade of authenticity and essentialization, but as a defining perspective of authority in the narration of what the city is. The "marginal" author is both subject and object of the composition. This collective self is a witness to urban realities and a certain authority at the moment of representation, which, in fact, is a kind of "presentification" of marginalization, i.e. a mechanism that transcribes urban experience into script. ${ }^{20}$ Such a mechanism is similar to representation insofar as it brings diverse experiences into the text through use of a lexicon of terms, such as "periphery," "margin," "bridge," "ghetto," "back alley," "quilombo" (settlements originally founded by escaped slaves, dating back to the seventeenth century) and "shantytown" (favela) in order to understand the various types of situations afforded by urban mobility.

Implicit in the following text, "Eu viela" (a play on words: "I saw her / I alley"), is the experience of mobility between peripheral neighborhoods and urban centers. Poets challenge conventional metaphors in their texts with the ultimate objective of re-making the city:

Today I saw her [I alley] / She has changed so much / Stripped of ceramic tiles / Scintillating pebbles / And I saw her children / Like I used to be / Running around the alley / Content, innocent // The alley grows / Always the mother to yet another / A welcoming alley / For those who have nothing and no one / The alley gives shelter /

18 Original text: “Conjugue esse verbo / Errada consonância / Na maneira de dizer /| Nóis é Ponte e atravessa qualquer rio. // O nóis pra nós / É singular / O nóis pra nós / O plural é pessoal // Nóis é Ponte e atravessa qualquer rio / [...] Mostre força / Encare o real / Deixe de lado o mau / Sem ser bom de todo / Senão o mundo te faz tolo / E ninguém é biscoito / Pra se deixar comer. // Nóis é Ponte e atravessa qualquer rio. // Busque outra margem / Ser esperto não é vadiagem | Arco íris, lagoa / Numa boa / Segure o leme, atravesse a ponte. || Venha Periferia || Nóis é Ponte e atravessa qualquer rio."

19 A fragment from Nosso manifesto (Our manifesto) by the Coletivo Cultural Poesia na Brasa, Brasilândia, called "A elite treme" ("The elite trembles"). Original text: "A elite encontra-se nos grandes centros comerciais, rodeada pelas periferias que ela própria inventou / a periferia se arma e apavora a elite central / Nas guerras das armas, os ricos reprimem os favelados com a força do Estado através da polícia / Mas agora é diferente, a periferia se arma de outra forma / Agora o armamento é o conhecimento, a munição é o livro e os disparos vêm das letras [...]".

20 In the end, as the writer Ferréz is wont to say, "to live inside the topic is complicated" (see, for example, Resende, 2008: 35; also Coronel, 2013: 29). The situation is full of paradoxes and traps that fix the place of origin of the author as genuine and literal (Ferréz 2006, back cover material). "I don't want to be a chronicler of hell for my entire life. I already live it. To have to ruminate on this too is painful” (Ferréz, 2012: 32). 
To dream of a better life / Danger lies on the corner / But I've seen her worse / the alley is worse // An alley disrespected / As though it were nothing / Even the women stopped by the cops / Just for living in a favela / An alley discriminated / An alley fallen silent / An alley washed clean / Of blood from an ambush // Dead end alley / Or ending on a big flight of steps / Alleys linking up / Spreading the occupation / Alley and the population / Of the favela / A work party by candlelight / Against the darkness of the cell // Helpless alley / Without any address | Flooded alley / Without a manger for the crib / Dimly lit alley / Full of compost and garbage / Frightened alley | Watching the guy sweep up the girls // Bare-foot alley / Taking care where you tread / Rocks roll, a fall is certain / Nobody is unaware / So it's an alley afterall / Look carefully / Step slowly / Because that's how things go down // Barricaded alley / After the death of a daughter / Executed / By a cartel / Alley up in flames / Under gunfire and gas / The elderly, infants and ladies / With no right to peace // Afterwards / The alley is even stronger than before / Even with its children badmouthed / As criminals / An alley rebuilt / By the neighbors / An alley more united / We are no longer alone ||Alley waiting for the lookout / Up on the roof / An alley going about its business | Doesn't put up with snitches / An alley under siege / By the police news / An alley interrogated / By the local cops // An alley marginalized / By society as a whole / An alley criminalized / For being a community / Because it is persecuted / Because it is suspect / Perhaps because it lives its life / In a narrow perspective // If she could talk / She'd hold a rally / Maybe that way / life on the periphery would improve / But whatever she might declare / Will be used against her / What isn't a tree-lined avenue / Is just an alley // When I first saw her [I alley] / It wasn't love at first sight / I thought she was ugly / Awkward and vulgar / Today I understand her / And the people who live in her / And I am not ashamed to say / It's us favela! (Shabazz, 2010: 37)

Shabazz's poem is an obvious example of play with linguistic form that makes direct reference to the urban and historical configurations of São Paulo's outskirts. Beyond the alliterations (more present in the original language) and the personification of the alley, Dugueto Shabazz plays with the semantics of territory. He combines indictments related to the social conditions of the Afro-Brazilian and favela populations and individual memory. "Alley" or viela alludes to a narrow street in the urban periphery, one that is stigmatized, disrespected, a dead end, occupied, dark, unprotected, trashed, and always under suspicion. The narration possesses a movement, which, Patrocínio (2013) suggests, draws its inspiration from rap and employs the keywords of "way, way back" and "today" to convey the process of marginalization that occurs over time. Furthermore, the text flows with descriptions of the play of children, maternal caretaking and, despite all the challenges, a community unity, a collective fortification and, ultimately, an unabashed declaration of pride: "é nóis, favela!"

21 Poem by Dugueto Shabazz, "Eu Viela." Original text: “Hoje eu viela / E ela mudou bastante / Mesmo ainda sem ladrilhos / De pedrinha cintilante / E vi seus filhos / Como eu antigamente / Correndo por ela / Contentes, inocentemente // Viela crescendo / Sempre sendo mãe de mais alguém / Viela acolhendo / Os que nada têm, nem a ninguém / Viela dando abrigo / Pra sonho de vida melhor / Na esquina há perigo / Mas já viela pior// Viela desrespeitada / Como se fosse nada / Até as tia enquadrada / Só por ser favelada / Viela discriminada / Viela calada / Viela lavada / De sangue na fita dada // Viela sem saída / Ou se acabar no escadão | Viela encontrando outra / Aumentando a ocupação / Viela e a população / Da favela / Um mutirão de vela / Contra a escuridão da cela |/ Viela desamparada | E sem endereço / Já viela alagada / E sem manjedoura pra berço / Viela mal iluminada / E cheia de lodo / Viela assustada / Vendo o bicho passar o rodo || Viela descalçada / Não se pisa sem cuidado / Pedras rolam, tombo certo / Ninguém tá desavisado / É viela, então / Vê direito / Pisa devagar / Que o bagulho é daquele jeito // Viela em barricada / Pela morte d’uma filha / Executada / Por organizada quadrilha / Viela em chamas / Debaixo de tiro e gás / Anciões, bebês e damas / Sem direito à paz || Depois disso / Ainda viela mais forte que antes / Mesmo com filhos difamados / Como meliantes / Viela ser reconstruída / Pelos vizinhos / Viela mais unida / Não estamos mais sozinhos / Viela guardando campana / De cima da laje / Viela que na atividade / Não admite cagoetage / Viela assediada / No jornal policial / Viela interrogada / Pela seccional // Viela marginalizada / Por toda sociedade / Viela criminalizada / Por ser da comunidade / Por que ela é perseguida / Porque é suspeita / Será por viver a vida / Em perspectiva estreita / Se ela falasse / Um comício faria / Talvez assim melhorasse / A vida na periferia / Mas o que ela declarar / Será usado contra ela / Que não é alameda / É apenas viela // Quando eu a vi / Não foi amor ao primeiro olhar / A achava feia / Constrangedora e vulgar / Hoje eu entendo ela / E a gente que vive nela / Que como eu não tem vergonha em dizer / É nóis favela”. 


\section{Combining Materiality with Mobility}

In general terms, one can say the sarau performer-cum-author embraces extreme locality through a thick description of the mundane things around her/him and seeks to diffuse such specific knowledge across the city. In so doing, $s /$ he not only links points on an urban map but also incorporates the journey as expressive culture. The routine of sarau signification becomes, in part, the routine of travel.

Sarau performers are heterogeneous in their expression of space as an accumulation of encounters and mobility. Some, often older veteran performers, such as Sérgio Vaz from the article's introduction, focus on the local transformation of mundane local spaces such as bars, "the only thing the State gave us" in his words, into cultural centers. Mobility comes in attracting like-minded people from other peripheral localities to the neighborhood sarau. As literary scholar Lucía Tennina describes, one can think of the sarau as an act of renaming neighborhoods and urban districts by way of sarau landmarks:

One can now affirm that the periphery is not simply a delimited space in terms of economic value and social structure; rather, it is an affective mapping of sarau circuits and its participants. In this manner, the stigmatized neighborhoods of Capão Redondo, Campo Limpo and Brasilândia, for example, become known as the neighborhood of the "Sarau of Vila Fundão," "Binho's Sarau" and "Brasa Poetry Sarau." (Tennina, 2013: 13)

For Banks, a veteran B-boy from hip hop who in recent years has become increasingly involved in saraus and slam poetry, the sarau is the "new window display of the periphery." ${ }^{22}$ While Vaz (2008) saw the sarau primarily as a force of local change, Banks emphasized the sarau as a collective vitrine or window display, and for this reason he became more geographically mobile traveling to saraus almost daily to contribute to the general "display." And others still, such as Rodrigo Ciríaco, a relatively successful self-published author of marginal literature, frequent performer at saraus and creator of Sarau dos Mesquiteiros in the East Side of the city, believe that material production, i.e. books and literature, is a way to occupy public space.

The marginal literature press is beginning to share the space of local corner bars, sold alongside sacks of charcoal for the typical Saturday barbecues and bottles of cachaça. Literary production imposes a kind of presence and marks a certain identification. In his interactive book Vendo pó... esia, a play on words, Seeing/I sell powder/poetry, that references how dwellers of the urban periphery are stigmatized as drug pushers, pó is a term for cocaine powder as well as the first syllable in poetry, he declares: "this is a book-object to read and move and be active" (Ciríaco, 2016: back cover). The implication is that by turning discourse into a thing, poets and sarau performers circulate identities and mark city spaces.

Beyond incursions into formerly abject spaces (dilapidated public parks) and marginalized private spaces (corner bars), sarau participants also encounter the state and have had a significant impact on its institutions, most commonly schools and public libraries. A visible example of this interaction is the CEU (Unified Education Center). As part of a public policy introduced in the early 2000 s by former mayor Marta Suplicy, the CEUs helped change the educational landscape in São Paulo's periphery (see Pardue, 2007). These large structures combine formal education and organized social activities in a single institution. The idea was that the CEUs would compensate for some of the spatial inequalities in the periphery, including the scarcity of public parks, libraries and recreation centers. The saraus, among other popular community groups, work to claim a percentage of the budget and make their presence felt.

In June 2014, DJ Erry-G pulled up to Alvarenga CEU, located in a far-flung peripheral neighborhood on the South Side of São Paulo. His car, its seats piled with vinyl records, sound equipment and the odd misplaced sandal and set of earphones belonging to his pre-teen daughter, coasted into a parking spot next to the back door of the CEU's auditorium. The winding route of the bus ride along the Alvarenga highway,

22 This phrase appeared several times in fieldwork interviews. Sadly, Banks died in late 2017, which itself has generated a number of saraus and slam events in his homage. 
overlooking the huge Billings Reservoir, had left us disorientated. Struggling to find our bearings, we met a rushed but welcoming Erry-G. "Today is all about the Guerreiro Productions Web Radio show. We'll have a couple of guests. I try to match up the young and new with seasoned veterans. The format is sarau with interlude sounds from myself and the ever-present MC skills of Oswaldinho," Erry-G explained.

The CEU Alvarenga was a steady gig for Erry-G, a professional DJ who has lived his whole life in makeshift housing in various neighborhoods located in the precarious watershed regions of the Billing Reservoir. As a tireless cultural entrepreneur, Erry- $G$ travels back and forth across São Paulo throughout the week and on the weekends. Yet he continues to reside in Alvarenga and is dedicated to the CEU. Oswaldinho, a long-time journalist, editor and Afro-Brazilian activist, sees Alvarenga and the CEU in terms of a "pilgrimage," an almost spiritual service undertaken to maintain his connections to what was an important area of labor activism during the 1960 s and yos and then later black activism. "I live on the North Side of the city and I don't mind making this trek. It is a journey of the soul for me. I hope I can share a bit of my experiences with the local kids inside the CEU. Let's see how it goes today." Despite their differences in geographical orientation and professional goals, both Erry- $G$ and Oswaldinho share the cultural, historical and political information from their inter-urban travels as part of their management of the local sarau.

When on the turntables, Erry-G speaks little, occasionally interjecting a quick remark connecting a break beat or interlude mix to a spot outside São Paulo or a historical moment. "Catch Z'Africa Brasil's new release. It uses a beat based on this tune." For his part, Oswaldinho plays the crowd and is conscious that the majority of audience members are listening and checking video clips from the internet. He thus combines interview questions for the sarau participants with mini-history lessons on Luís Gama, the nineteenth-century black Brazilian writer and abolitionist, whose statue is the destination for an annual march through São Paulo that Oswaldinho helps organize. He peppers this more academic information with news on current events in a bulletin style.

On this particular day, the new group being featured was SarauArte, whose name involves a straightforward combination of the words sarau and art. The members introduced themselves explicitly in terms of spatial occupation:

We are mostly from Cidade Tiradentes. We all kind of knew each other before and a couple of us had noticed this abandoned orphanage nearby. We decided to take it over and transform it into a cultural center. SarauArte is a collective of a dozen individuals and it stands as one of the results of that occupation.

SarauArte then broke up into smaller groups featuring guitar duets in the country music style known generally as caipira. They performed classical guitar pieces, Brazilian rock and MPB (a catch-all category of "Brazilian Popular Music" generally derived from samba and bossa nova). SarauArte culminated their presentation with a piece called "12-bit," an allusion to video games, an original composition mixing video game background music and European classical compositions. The example of SarauArte playing at CEU Alvarenga demonstrates the penetration of saraus into public educational institutions and state-sponsored leisure and youth activity spaces. We emphasize the role of travel and trajectory in the production of the CEU space as expressed in the narratives of Erry-G, Oswaldinho and the SarauArte members. This brief ethnographic account complements that of the marginal literature performers who consistently reinforce the value of place as both subject matter and a point of encounter in their overall efforts to recuperate the periphery as a producer of culture and the sarau as a mechanism of "city-making." 


\section{Moving Towards Urban Theory}

In this article, we have delineated potential new approaches to the dynamic of the sarau movement by highlighting the materiality of mobility. Following theorists such as Agier and Massey, our approach to the city (and saraus) is neither normative nor evolutionary. There is no bounded place called São Paulo in which human actors operate. Nor are the socio-political critiques emanating from the saraus part of a discursivespatial development towards a new and improved city. In São Paulo, individuals experience and participate in saraus by relating their daily activities and their symbolic goods to peripheral urban spaces. They also create and amplify "marginal voices" emergent from working-class peripheral urban neighborhoods by exploring a variety of artistic languages, as well as community empowerment and the democratic right to the city. Such transformations are what we are primarily interested in and what we propose is, in effect, "city-making."

Overall, saraus emphasize the relatively underdeveloped link between literature and social interaction by intensifying the performativity of text. In so doing, they whet the appetite of audience members who expect a certain level of experience to be attached to literature. However, these are not simply private experiences but shared ones to be enjoyed in the moment of poetry recitation and also, importantly, in the interactive experiences of transportation and mobility. Saraus signify a trip, then, and the frequency of these cultural and social events means that there is a routinization and socialization of local travel. Our contribution to urban theory is the approximation of the aesthetic, performative and discursive with the spatial and political in the making of the city.

The fact that the various urban peripheries are the destination of mobility, social interaction, political awareness and aesthetic pleasure is noteworthy. Saraus are more than just an inversion of conventional notions of urban geography with "new" peripheral locations as destination points for participants and curious consumers. Our analysis suggests a theoretical and empirical contribution to city formation and sociality: namely, saraus demonstrate that mobility and the encounter are not simply temporary conduits and extraneous interactions but rather constitutive experiences of social knowledge.

This argument emerges from the premise that things, like city buildings, corner bars, alleyways and bus depots are social facts. Setting out from this basic assumption, we have examined agency, and by extension visibility, power and the production of new meanings, in terms of a subject-object intersectionality contextualized by a range of social inequalities and differences. Furthermore, movement and encounters inform this field of socio-material engagement. The present moment represents a certain clash between a "paradigm of mobility" (see Sheller, 2011; Urry, 2007) in which people try to reckon with regimes of value and judgment associated with fluidity and flexibility, and the existential investment involved in the acts of dwelling and emplacement.

Such realities frame the contemporary urban dialectic, a dynamic that produces new meanings for cities via new forms of agency that often challenge the new tensions articulated around difference and likewise express new sensibilities of solidarity as a result of an awareness of difference. The point here is that, following the concept of locality proposed by Massey (2005), Pennycook (2010) and others, an investment in "place," such as saraus, is not a rejection of the global or more specifically mobility. Rather, and this is our main theoretical contribution to the debate, when we approach place as necessarily a performance of encounters involving both experiences and the materialization of mobility, we are able to jettison the conception of the periphery as an enclave, a sorry leftover of haphazard urbanization.

To finish, we turn to the politics of social science and especially the foundational work of radical geographers such as Henri Lefebvre, Doreen Massey and David Harvey. Saraus are manifestations of a real and growing grassroots movement that have transformed city space into a socio-political and cultural project based on the idea of "rights to the city." Urban spaces have become material and symbolic stages of 
struggle, which performers use as existential resources. Our argument (and our theoretical and political wager) is that saraus are the quintessential event of the marginal literature movement and engender both self-transformation (and thus identification) and "city-making," to return to Michel Agier's pithy turn of phrase. In so doing, the sarau movement, along with contemporary marginal literature as a whole, contribute to the construction of a new imaginary of the public space and the city, occupied by the socially excluded and racialized peripheries.

While it has become banal for scholars to claim that popular movements influence the reckoning of public space and the contours of civil society, our contribution has been to unravel the precarious but promising connections between urban mobility and the material dimension of the city. We have theorized this relationship in terms of culture and performance rather than infrastructure and planning, thereby allowing for a real, engaged sociology and anthropology of the city from the perspective of marginalized working-class artists, a class of residents who inhabit and dwell perhaps more expansively in the city than anyone else.

Revision: David Rodgers

Received: December 12, 2016; Approved: May 26, 2017

\section{References}

ADERALDO, Guilhermo. 2016. "Entre imagens e imaginários: estética e política nas intervenções visuais/ audiovisuais de coletivos culturais paulistanos”. In: L. Kowarick \& H. Frúgoli Jr. (eds.), Pluralidade urbana em São Paulo. São Paulo: Editora 34, v. 1, p. 55-79.

. 2013. Reinventando a "cidade": disputas simbólicas em torno da produção e exibição audiovisual de "coletivos culturais" em São Paulo. Tese de doutorado, Programa de Pós-Graduação em Antropologia Social, USP.

AGIER, Michel. 2015. "Do direito à cidade ao fazer-cidade: o antropólogo, a margem e o centro". Mana. Estudos de Antropologia Social, 21(3): 483-498.

ASSIS, Machado de. 2007. 50 contos escolhidos de Machado de Assis. Seleção, introdução e notas de John Gledson. São Paulo: Companhia das Letras.

BASÍLIO, Ana Luiza; MOREIRA, Jéssica. 2014. "Saraus das cidades-sede colaboram com a mobilização comunitária”. Porta Aprendiz. See: http://goo.gl/iueRys. Accessed October 10, 2016.

BIN, Marco Antonio. 2009. As redes de escritura na periferia. Tese de Doutorado, Programa de Pós-Graduação em Ciências Sociais, PUC-SP.

BRASA, Coletivo Cultural. 2009. Antologia poética da Brasa, vol. IV. São Paulo: Coletivo Poesia na Brasa.

CAMARGOS, Marcia M. R. 1999. A Villa Kyrial e o imaginário da Belle Époque paulistana (1900-1930). Tese de doutorado, Departamento de História, USP.

CIRÍACO, Rodrigo. 2016. Vendo pó...esia. São Paulo: Editora Nós.

CLEARY, Richard. 2017. “The architecture of sports”. In: Places Journal, July 2017. See: https://doi. org/10.22269/170725. Accessed August 1, 2017. 
COHEN, Sarah. 2012. “Urban musicscapes: mapping music-making in Liverpool”. In: Les Roberts (ed.), Mapping cultures. London: Palgrave Mac Millan. pp. 123-43.

CORONEL, Luciana P. 2013. "A escrita da cidade partida”. Estudos de Literatura Brasileira Contemporânea, Brasília, 42: 29-45.

COSTA, Antônia. 2009. "Fazendo do nosso jeito": o audiovisual a serviço da "ressignificação da favela". Dissertação de mestrado, Departamento de Ciências Sociais, PUC-RJ.

COTA, Giselle F. 2008. Cinema da quebrada: oficinas audiovisuais na periferia paulistana e seus desdobramentos. Dissertação de mestrado, Departamento de Comunicação, USP.

CURTA Saraus. 2010. Direção: David Alves da Silva. Produção: Alisson da Paz, Daniela Embón, Gil Marçal, Penha Silva. Brazil: 2010. DVD (15 min), sound, color.

D’ANDREA, Tiarajú. 2013. A formação dos sujeitos periféricos: cultura e política na periferia de São Paulo. 2013.

Tese de doutorado, Programa de Pós-Graduação em Sociologia, USP.

DANZIGER, Walner. 2012. "Eles não usam Black Power”. Rebosteio, 4: 62-67.

ESLAVA, Fernando. 2008. "Literatura marginal: voz letrada de la periferia". Hojas Universitarias, 60: 77-82. . 2004. "Literatura marginal: o assalto ao poder da escrita". Estudos de Literatura Brasileira Contemporânea, 24: 35-51.

FELIX, João Batista de J. 2005. Hip Hop: cultura e política no contexto paulistano. Tese de doutorado, Programa de Pós-Graduação em Antropologia Social, USP.

FERRÉZ. 2012. "Fechado para balanço: entrevista com Ferréz". Itaú Cultural, 38: 30-35. . 2006. Ninguém é inocente em São Paulo. Rio de Janeiro: Objetiva.

GUPTA, Kamla; YESUDIAN, P. Princy. 2006. "Evidence of women's empowerment in India: a study of sociospatial disparities". Geo Journal, 65(4):365-80.

HAESBAERT, Rogério. 1997. “Territorio, poesia e identidade”. Espaço e Cultura, 3: 17-29.

HAPKE, Ingrid. 2012. "Literatura marginal como literatura de testimonio, más allá de lo impresso".

No-Retornable, 11. See: www.no-retornable.com.ar/v11/brasil/hapke.html. Accessed May 15, 2017. ; TENNINA, Lucía; SILVA, Mário Augusto Medeiros; NASCIMENTO, Erica Peçanha (orgs.). 2015.

Polifonias marginais. Vol. 1. Rio de Janeiro: Aeroplano Editora.

HARVEY, David. 2012. Rebel cities: from the right to the city to the urban revolution. New York: Verso. . 2005. Spaces of capital: towards a critical geography. New York: Routledge.

HOLMES, Tori. 2016. "Reframing the favela, remapping the city: territorial embeddedness and (trans) locality in 'framing content' on Brazilian favela blogs". Journal of Latin American Cultural Studies, 25(2): 279-319.

KOSTAKIS, Vasilis; BAUWENS, Michel. 2014. Network society and future scenarios for a collaborative economy. Basingstoke, UK: Palgrave Macmillan.

LEFEBVRE, Henri. 1968. Le droit à la ville. Paris: Anthropos.

LEVINSON, Amber Maria. 2005. Jovens vozes em cena: experiências de integração e autodeterminação através das artes performáticas no Rio de Janeiro. Dissertação de mestrado, Programa de Pós-Graduação em História Social, PUC-RJ.

LORDE, Audre. 1985. "Poetry is not a luxury". In: Sister outsider: essays and speeches. Trumansburg, NY: Crossing Press, pp. 36-39.

MASSEY, Doreen. 2005. For space. London: Sage Publications.

MEDEIROS, Elton 2002. "Oral tradition and Brazilian popular music". Yearbook for Traditional Music, 34: 1-8. MUNIZ JR, José S.; OLIVEIRA, Lucas A. 2015. "Literature from the periphery of São Paulo at the Buenos Aires International Book Fair". Journal of Arts Management, Law, and Society, 45: 119-133. 
NASCIMENTO, Erica P. 2010. "A periferia de São Paulo: revendo discursos, atualizando o debate". Rua,

UNICAMP, 2: 111-127.

. 2011. É tudo nosso! Produção cultural na periferia paulistana. Tese de doutorado, Programa de Pós-

Graduação em Antropologia Social, USP.

. 2006. "Literatura marginal": os escritores da periferia entram em cena. Dissertação de mestrado, Programa

de Pós-Graduação em Antropologia Social, USP.

. 2009. Vozes marginais na literatura. Rio de Janeiro: Aeroplano/Fapesp.

2014. “Vozes negras e periféricas na literatura: pode o Estado amplificá-las?” In: Cidinha Silva (ed.),

Africanidades e relações raciais. Brasília: Ministério da Cultura \& Fundação Palmares, pp. 290-300.

NISHIJIMA, Marislei; IVANAUSKAS, Terry M.; SARTI, Flavia M. 2016. "Evolution and determinants of

digital divide in Brazil (2005-2013)". Telecomunications Policy, in press.

NYANZI, Barbara; NYANZI, Stella; WOLFF, Brentlff; WHITWORTH, James. 2005. "Money, men and markets: economic and sexual empowerment of market women in Southwestern Uganda”.Culture, Health \& Sexuality, $7(1): 13-26$.

OLIVEIRA, Lucas A. 2016. "Speaking for themselves: observations on a "marginal" tradition in Brazilian Literature". Brasiliana - Journal for Brazilian Studies, 5(1): 441-471.

ONG, Aihwa. 1999. Flexible citizenship: the cultural logics of transnationality. Durham, NIC: Duke University Press.

PARDUE, Derek. 2009. "An anthropologist in São Paulo, Brazil: making a case for spatial knowledge”. In: George Gmelch and Walter P. Zenner (orgs.), Urban life: readings in the anthropology of the city. Long Grove, IL: Waveland Press, pp. 157-169.

. 2007. "Hip hop as pedagogy: a look into 'heaven' and 'soul' in São Paulo, Brazil”. Anthropological

Quarterly, 8o(3): 673-708.

. 2008. Ideologies of marginality in Brazilian hip hop. New York: Palgrave McMillan.

2014. "Pop Speculation: tracing geography, investment, and identity in Sao Paulo's Hip Hop and

Open Mic Scenes". Alternativas, 2: 1-23.

PATROCÍNIO, Paulo R. 2013. Escritos à margem. Rio de Janeiro: 7 Letras/FAPERJ.

PAULA, Leonora Souza. 2016. "Literatura periférica: challenging São Paulo’s cultural segregation”. The

International Journal of the Constructed Environment, 7(2): 13-24.

PENNYCOOK, Alastair. 2010. Language as a local practice. New York: Routledge.

PEREIRA, Alexandre B. 2010. "A maior zueira": experiências juvenis na periferia de São Paulo. Tese de doutorado,

Programa de Pós-Graduação em Antropologia Social, USP.

PEZÃO, Marco. 2013. Nóis é ponte e atravessa qualquer rio. São Paulo: Reza Brava.

RESENDE, Beatriz. 2008. Expressões da literatura brasileira no século XXI. Rio de Janeiro: Cia da Palavra.

REYES, Alejandro. 2013. Vozes do porão: a literatura periférica/marginal do Brasil. Rio de Janeiro: Aeroplano/

Tramas Urbanas.

ROBERTS, Les. 2012. "Mapping cultures: a spatial anthropology". In: Mapping cultures: place, practice, performance. London: Palgrave MacMillan, pp. 1-28.

SALIBA, Elias Thomé. 2001. "Nos tempos da Villa Kyrial". Revista USP, 50: 303-307.

SALLES, Ecio de. 2004. "A narrativa insurgente do hip-hop". Estudos de Literatura Brasileira Contemporânea, 24: 89-109.

SALOM, Julio Souto. 2014. "La literatura marginal periférica y el silencio de la crítica". Revista Chilena de Literatura, 88: 235-264. 
SHELLER, Mimi. 2011. "The emergence of new cultures of mobility: stability, openings, and prospects". In: G. Dudley, F. Geels, and R. Kemp (eds.), Automobility in yransition? A socio-technical analysis of sustainable transport. London: Routledge, pp. 180-202.

SILVA, José Carlos Gomes da. 2011. "Sounds of youth in the metropolis: the different routes of the hip hop movement in the city of São Paulo". Vibrant, 8(1): 68-94.

SILVA, Mário Augusto M. 2013. A descoberta do insólito: literatura negra e literatura periférica no Brasil (19602000). Rio de Janeiro: Aeroplano.

SILVA, Rogério. 2011. Cultura e violência: autores, polêmicas e contribuições da literatura marginal. São Paulo: Annablume.

SILVA, Simone. 2004. As rodas literárias nas décadas de 1920-30: troca e reciprocidade no mundo do livro.

Dissertação de mestrado, Programa de Pós-Graduação em Antropologia Social, Museu Nacional, UFRJ. ; TENNINA, Lucía. 2011. "Literatura marginal de las regiones suburbanas de la ciudad de San Pablo: el nomadismo de la voz." Ipotesi, 15(2): 13-29.

SMITH, Christen A. 2015. "A escrita 'uterina preta' de Mjiba: Elizandra Souza and the New Black Female Poets of Brazil". Journal of Latin American Cultural Studies, 24(3): 405-415.

SCHWARZ, Roberto. 2009. Cultura e política. São Paulo: Paz e Terra.

SHABAZZ, Dugueto. 2010. "Ritmo e poesia": entrevista com Dugueto Shabazz. Caderno de referências educação com arte: oficinas culturais. São Paulo: CENPEC, pp. 36-39. See: https://goo.gl/6wZmfZ. Accessed January 30, 2017.

SORJ, Bernardo; FAUSTO, Sergio. 2015. Internet e mobilizações sociais: transformações do eespaço público e da sociedade civil. Rio de Janeiro: Plataforma Democrática.

TAVARES, Vilma Costa. 2001. À flor da pele: vida e morte em tempo de tribos. Tese de doutorado em Letras, PUC-RJ.

TENNINA, Lucía. 2013. "Saraus das perfierias de São Paulo: poesia entre tragos, silêncios e aplausos". Estudos de Literatura Brasileira Contemporânea, 42: 11-28. . 2010. “Paratextos y 'saraus' de poesia”. Darandina, 3(2). See: https://goo.gl/giGNjr. Accedded May 2, 2016.

URRY, John. 2007. Mobilities. London: Polity.

VAZ, Sérgio. 2008. Cooperifa: antropofagia periférica. Rio de Janeiro: Aeroplano.

WERLEN, Benno. 2004. "Géographie culturelle et tournant culturel”. Géographie et Cultures, 47: 7-27.

ZENTGRAF, Kristine M. 2002. “Immigration and women's empowerment: Salvadorans in Los Angeles”. Gender and Society, 16(5): 625-46.

\section{Derek Pardue}

Cultural Anthropologist, Associate Professor and Coordinator of Brazilian Studies, Department of Global Studies, Aarhus University, Denmark.

E-mail: dppardue@gmail.com

\section{Lucas Amaral de Oliveira}

Programa de Pós-Graduação em Sociologia, Universidade de São Paulo, Brasil. This work was supported by the São Paulo Research Foundation (FAPESP) under Grant 2014/01074-0 E-mail : lucas_amaral_oliveira@hotmail.com 